\title{
Does Corporate Sustainability Create Long-term Shareholder Value? Evidence from Public Listed Companies in Indonesia \\ Mustaruddin Saleh
}

Faculty of Economics and Business

Universitas Tanjungpura

Pontianak, Indonesia

e-mail: mustaruddin@ekonomi.untan.ac.id

\section{INDONESIA}

\section{ABSTRACT}

\begin{abstract}
Corporate sustainability is a business approach that creates long-term shareholder value by exploiting opportunities and managing risks created from economic, environmental, and social activities. The purpose of this study is to analyze the influence of corporate sustainability and corporate governance on a firm's value. The population in this study comprised all the firms which are registered on the Indonesia Stock Exchange (IDX) and that were also registered as participants of the Indonesian Sustainability Report Awards (ISRA). Using the purposive sampling technique, 75 observations were selected. From the hypothesis testing results, it was concluded that the company's sustainability index and corporate governance variables have a positive but not significant effect on the firm's value. The results of this study are in agreement with previous research (Eccles et al., 2014; Lourenco et al., 2012; and Wagner, 2010). The result also recommends that companies must be more actively involved in the sustainability reports with regards to the economic, social, and environmental aspects. This will affect the performance of the company and its output in the context of sustainable development.
\end{abstract}

\section{Keywords: corporate sustainability, corporate governance, firm value, environment, and social.} JEL Classification: G11, Q01, Q56.

\section{Introduction}

At present, corporate sustainability appears to be a mandatory term used to describe companies competing with each other in the market. Corporate sustainability is a business approach that creates long-term shareholder value by exploiting the opportunities and managing the risks created from economic, environmental, and social activities (DJSI). Sustainability, in its simplest form, is about how to do it well now, without damaging the ability to do it well in the future. It is also about taking a holistic approach to making personal, government, and business decisions that place environmental awareness and social responsibility at par with a healthy economy. Sustainability is business-oriented as "the company's ability to achieve its business goals and increase long-term shareholder value by integrating economic, environmental and social opportunities into its business strategy." (Harmon et al., 2008).

Concerns for sustainable companies in Indonesia has shown an improving trend, whereby, in 2007, the number of firms that published sustainability reports was only 5 , but, by 2016, 85 firms had made and published their reports. The increasing awareness of companies to maintain the continuity of their business in the long-term has created an awareness of the importance of paying attention to the environmental aspects and community care so that they can continue to grow in the future. Concern regarding the sustainability of the companies must be implemented by good corporate governance (GCG), to improve their performance in the eyes of stakeholders. This study shows that corporate sustainability has been used by companies, environmental organizations, and consultants, etc., to seek justification for a company's sustainability strategy (Salzmann and Steger, 2005).

Sustainability reporting disclosure in Indonesia is still voluntary, and, currently, the issuance of ongoing reports in Indonesia is mostly based on the disclosure standards available in the Global Reporting Index (GRI). At the end of 2016, 49 companies listed on the IDX had published sustainability reports. The high enthusiasm for the continued issuance of reports shows that the publishing of these reports is important, especially in terms of how companies integrate aspects of the environment, social, and good governance.

Research on the impact of corporate sustainability on company values shows mixed results, most shows that have a positive impact on the company's value in the eyes of stakeholders (Lourenco et al., 2012; Kaspereit and Lopatta, 2013; Jo and Harjoto, 2011; Eccles et al., 2014). Other studies showed that investment in CSR activities has a partial effect on the firm's value (Singh et al.,2017), while the research conducted by Wagner (2010) shows a moderate result. Other studies have negative impacts on the economic performance of the company (Wagner, 2005). In event study method found that announcements of the companies' sustainability reports do 
not have a significant market reaction (Guidry and Patten, 2010 and Cheung, 2011).

Given the increasing sustainability of corporate research in developed countries, empirical studies on the issue of corporate sustainability in developing countries are still limited (Goyal et al.,2013). Hence, the author is interested in conducting an empirical study of the impact of corporate sustainability on the value of companies listed on IDX.

\section{Literature Review}

\subsection{Theory of Sustainability of Management.}

Sustainability management performance can be explained using various established theoretical approaches. Kantabutra (2019) outlines in detail the various theories used to assess the company's sustainability performance, namely by using Self-determination theory; Stakeholder theory; Sustainable Leadership Theory; Complexity theory; Knowledge-based theory; Dynamic Capabilities theory; and Knowledge Management theory.

Stakeholder theory can be applied in the context of sustainability management (Hörisch et al., 2014). Thus, stakeholder theory helps position sustainability management. In the context of company sustainability, several parties have an interest in a company. In addition to the interests of shareholders, the company's sustainability also aims to meet the interests of other parties, such as employees, suppliers, consumers, creditors, the government, and others. So, the effort to maintain the company's sustainability continues to be carried out and supported by various parties.

Agency theory is also used in explaining the practice of corporate sustainability. This theory reveals that there is a relationship between the principal (as the owner of the company) and the agent (as the company manager) based on the separation of the ownership and control of the company, the separation of the insurer, decision making, and controlling functions (Jensen and Meckling,1976). The agency theory explains the problem of information asymmetry, the managers of the company know more about the internal information and future company prospects compared to the owner. Therefore, the manager is obliged to give a signal about the condition of the company to the owner, but, sometimes, the information submitted and accepted is not following the actual condition of the company. So, the managers try to convey a positive signal to outside parties of the company so that any information submitted can be used as a decision-making tool for those outside parties. If the company can implement its sustainability, then of course it will be responded positively by parties outside the company, such as investors, creditors, consumers, and others, which can be used as a signal that the company is trying to maintain the company's long-term sustainability.

Furthermore, the sustainability of the company is inseparable from the recognition of the community (consumers) of the existence of the company. The sustainability of a company depends on how far the community is willing to accept the existence of the company in its environment, such as its willingness to buy the products or services offered by the company. The legitimacy theory states that companies have a contract with the community. Dowling and Pfefer (1975) state that the legitimacy theory is a source for determining the existence of a company. A company is said to have legitimacy when its value system is aligned with the community value system, where the company is part of the community.

The characteristic of an organization legitimized by the community is following the rational and legal framework in the community. Even though the company has operating policies within institutional constraints, the failure of the company to adjust to the norms or customs accepted by the community will threaten the legitimacy of the company and the company's resources, which, ultimately, will threaten the survival of the company. Through disclosure, a company feels its existence and activities are legitimate. The existence of company management disclosures will provide more knowledge and information about the company to all users of the reports submitted; in this case, including the community. Hence, the public can know about all the activities and the performance of the company from the disclosure of the report.

\subsection{Corporate Governance}

Corporate governance (CG) has a broader agenda in the future. The focus of corporate accountability was initially oriented towards stockholders but is now broader, and corporate governance must also take into account the interests of stakeholders. As a result of this paradigm shift, corporate governance must consider issues, such as CSR. When companies are actively involved in CSR activities, they can create customer loyalty (Saleh et al., 2011). The governance of a company in the future must pay more attention to the needs of stakeholders. Disclosure of the economic, environmental, and social aspects is now a means by which companies communicate their forms of accountability to stakeholders. This is known as the triple bottom line reporting sustainability recommended by the GRI.

According to the OECD (Organization for Economic Cooperation and Development), "Corporate governance is a system for directing and controlling companies." There are several principles in implementing good corporate governance (GCG). According to the general guidelines of good corporate governance in Indonesia, the five main principles contained in good corporate governance-transparency, accountability, responsibility, independence, and fairness and equality-are needed to achieve business sustainability. Transparency, to maintain objectivity in conducting business, companies must provide material and relevant information in a way that is easily accessible and understood by stakeholders; 
Accountability, companies must be able to account for their performance transparently and fairly; Responsibility, companies must comply with the laws and regulations and conduct their business responsibility in terms of the community and the environment; Independence, the company must be managed independently; Fairness and equality, companies must always pay attention to the interests of the shareholders and other stakeholders based on the principle of fairness and equality.

\subsection{Sustainability Report}

Financial statements, which are financial aspects, and the reports on the corporate social and environmental responsibilities, which are non-financial aspects, can be combined by the company as a form of a report that has completeness and accuracy for the related parties.

Sustainability reporting is defined as a public report where the company provides an overview of the position and activities of the company concerning the economic, environmental, and social aspects to internal and external stakeholders (The World Business Council for Sustainable Development, 2002). In the sustainability report, there is a component commonly referred to as the triple bottom line, namely; profit, people, and planet. The meanings of each of these components:

\section{-Economic performance (economic performance) $=$ profit}

Economic performance reports the traditional measures of financial performance, and perhaps additional statistics related to economic performance, such as market share of products or information about developing new products.

-Social performance $=$ people

Social performance reports the performance measurements related to employee welfare, such as employee accident rates, training programs, and statistics on employee acceptance. This category also reports measurements of other social performance, such as charitable contributions, and company activities in shaping local, national, and international public policies.

\section{-Environmental performance $=$ planet}

Environmental performance reports on the impact of the service products and company processes on the environment; a component of the triple bottom line can report the release of pollutants into the public air and water, renewable utilization (non-renewable), and management of natural resources by the company.

Disclosure of sustainability reports following the GRIG3.1 must meet several standards. These standards are listed in the GRI-G3.1 Guidelines: 1) Economy-Concerning the impact that the company has on the economic conditions of stakeholders and the economic system at the local, national, and global levels; 2) Environment-Concerning the impact the company has on creatures in the earth and the surrounding environment including ecosystems, land, air, and water; 3) Human Rights-There is transparency in considering the selection of investors and suppliers/ contractors. In carrying out their activities, companies must always pay attention to the interest of stakeholders; 4) Society-Focus on the impact of the organization on the communities in which they operate and reveal the risks that might arise from interactions with other social institutions.

\subsection{Empirical Study}

Although empirical studies on the sustainability and corporate governance of values show mixed results, most of the results of previous studies have found significant positive effects. Other research concludes that the effect is partial. Also, using the event study method, it has been concluded that the content of information about the disclosure of sustainable reports does not provide an opportunity for investors to obtain above-normal profits.

The research conducted by Eccles et al (2014) concluded that companies that are active in disclosing company sustainability have a positive impact. This is because managers with high corporate sustainability, who have formal sustainability responsibilities obtain incentive compensation based on the sustainability matrix. Hence, such a company is preferred by stakeholders and is oriented towards long-term relationships. Also, companies that have high corporate sustainability have significantly superior stock prices and better accounting performance than companies that have low corporate sustainability. Furthermore, in the research of Jo and Harjoto (2011), in which they examine the impact of external and internal corporate governance and monitoring mechanisms on the choice of involvement in CSR on firm value, they concluded that involvement in CSR activities had a very strong and positive influence on the firm value.

Using the Dow Jones Sustainability Index (DJSI) to measure the effect of corporate sustainability performance (CSP) on the equity market value of North American public companies, the results of the study by Lourenco et al (2012) showed that CSP has significant explanatory power over stock prices. Kaspereit and Lopatta (2013) investigated whether corporate sustainability, as measured by the sustainable asset management (SAM) sustainability rating and sustainability reporting, is associated with the higher market valuation in the 600 largest European companies. Their investment results state that the relationship between CSP and market value is positive and that the relationship between the GRI report and market value is statistically significant, but not in all model specifications.

Wagner's research (2010), which uses the Kinder Lydenberg Domini financial database for the period 1992-2003 to analyze the relationship between corporate sustainability and economic performance with panel data estimation 


\section{(c) Center for Promoting Education and Research (CPER) USA}

www.cpernet.org

techniques, shows that the intensity of advertising has a moderate relationship with corporate sustainability performance and economic performance as measured by Tobin's q. However, several subsequent studies, such as Goyal et al. (2013); Wagner (2005); Gudry and Patten (2010); and Cheung (2010) show that the relationship between corporate sustainability and company value is not significant.

\subsection{Conceptual Framework and Hypothesis}

A company is actively involved in sustainability investment, it will maintain or enhance the company's reputation, prevent stakeholders and law enforcement authorities from taking action, and make the company a more attractive investment choice for socially responsible investors (Artiach et al.,2010). The company which adopts sustainability into firm strategies and practices will minimize the firm risk and create the long-term value of the company for their stakeholders (Yu and Zhao, 2015; Burnett et al., 2011). The investors will be penalized by the companies which have big profit with less active involvement in sustainability and the companies which can develop a high level of sustainability, and failure to partake in such a strategy are punishable by the markets (Lourenco et al., 2012; Lo and Sheu, 2007).

Empirical studies on the relationship of CSP and corporate value have been carried out in developed countries using a variety of economic and cultural perspectives with the result that there is no universal agreement (Goyal et al., 2013). More work needs to be done regarding this topic, especially in developing countries, which are still limited to conducting empirical studies on the influence of the company's sustainability performance on company value. There is a significant positive association between expected future performance measured by using stock price and the quality of sustainability reporting for ASX 200 firms from 2003-2005 (Bachoo, Tan, \& Wilson, 2013). Artiach et al (2010) revealed that the US companies with superior sustainability performance have significantly higher levels of growth and a higher return on equity than the usual companies. Yu and Zhao (2015) have performed an empirical study using a large sample size for the period between 1999 until 2011, which shows a positive relationship between sustainability performance and firm value. Whereas, Lourenco et al (2012) using North American companies as their samples find that CSP has significant explanatory power to firm value by use of share prices than accounting measures such as earrings and book value of equity. Based on the description above, the following research hypothesis is proposed.

H1: The companies which actively involved in corporate sustainability have a positive effect on the firm's value.
The study of the relationship between corporate governance and corporate value has been carried out intensively by many researchers. In line with the increasing attention of stakeholders on the separation between management as agents and shareholders of the company as a principal, the study of corporate governance and how it affects the value of the company becomes important. Muller (2014) revealed that board independence and the proportion of foreign directors among the total number of directors have a significant and positive effect on the performance of the company. Nguyen and Fatt (2007) discovered the Australian public companies, the smaller board size is more effective in representing the interests of shareholders and has a positive influence on the value of the company, and an increase in the number of boards decreases the value of the company. It was also found that the relationship between board size and company value was not completely linear. While, Jo and Harjoto (2011) find that the impact of analysts by firms that engage in CSR on firm value is strongly positive, while the board leadership, board independence, blockholders' ownership, and institutional ownership play a relatively weaker role in enhancing the firm value.

Different findings were made by Guest (2009). In the UK, board size has a strong negative effect on the UK listed firms due to boards playing a weak monitoring role and therefore any negative impact of large board size is likely to reflect the malfunction of the board's advisory role. Then, Eulerich et al (2014) noted that the effects of various board diversity characteristics on German firm performance, mostly found negative results, especially regarding age and national diversity. This may be because huge internationality on boards can reduce communication between board members and the big age differences may improve decision-making processes. The comprehensive study using 22 developed countries' data finds that a strong and positive relationship between companylevel corporate governance and firm valuation (Amman et al, 2011). Based on the description above, the following research hypothesis is proposed.

H2: The companies which are actively involved in practicing good governance have a positive effect on the firm value.

Based on the description of the theoretical and empirical reviews above, this research analyses the influence of corporate sustainability (CS) and corporate governance (CG) on the value of a firm (FV) listed on the IDX. To give a clear direction, the relationship between the variables in this study can be described in the form of the conceptual framework shown in Figure 1. 


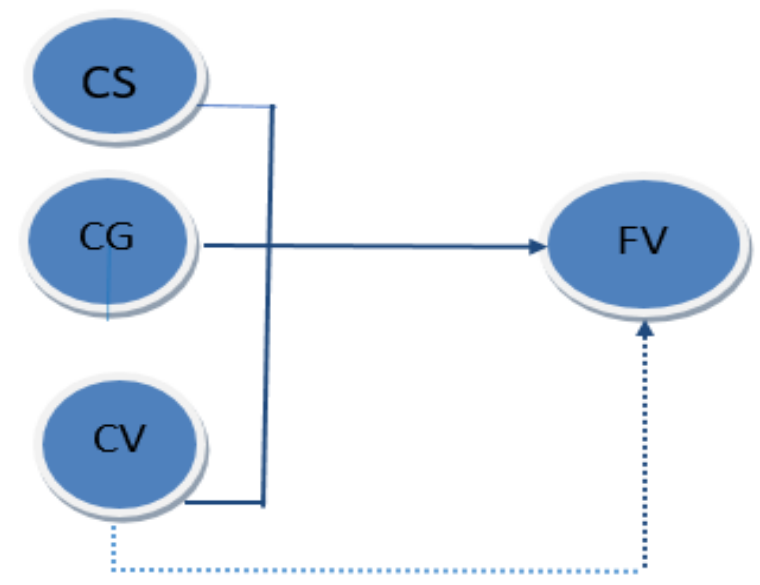

Figure 1. Conceptual Framework

From the figure, it can be seen that this study was conducted using two models, namely, model 1, where firm value, which is measured using Tobin's q and return on assets (ROA), is influenced by corporate sustainability and governance. Corporate governance is measured by the board of commissioners and audit committee variables, and control variables $(\mathrm{CV})$ are measured by company size variables. Whereas, for model 2, firm value, which is measured using Tobin's q, market to book value (MBV), and return on assets (ROA), is influenced by corporate governance, which is measured by the board of commissioner's variable and the audit committee; the control variable is measured by the size (SIZE) of the company.

\section{Research Method}

The population in this study comprises all the companies registered on the IDX from 2013 to 2018, that are also registered as participants of the Indonesian Sustainability Report Awards (ISRA). The sample selection in this study was the purposive sampling technique.

The dependent variable in this study is firm value, which is measured using three alternative variables; Tobin's $q$, market to book value. The independent variables are utilized three variables, namely, Sustainability Report (SR); the company sustainability report stated that the sustainability reporting index (SRI) will be assessed by comparing the number of disclosures made by the company with the number of disclosures required in the global reporting initiative (GRI), including indicators of disclosure items; economics, environment, labor practices, human right, society, and product responsibility. The size of the board of commissioners in a company (BC) The size of the audit committee (AC) is the number of members of the audit committee in one company. Last, is the size of the company which is measured by the total asset of the company obtained from the company's annual report. The size of the board of commissioners is calculated by calculating the number of members in the board of commissioners in a company mentioned in the annual report.

The multiple regression models used in this study are as follows:

Model 1: Tobin's $q=\alpha+\beta 1 \mathrm{CSI}+\beta 2 \mathrm{ROA}+\beta \mathrm{DER}+\beta 4 \mathrm{CR}+\beta 5 \mathrm{LnASSET}$ $+\mathrm{e}$

Model 2: Tobin's $q=\alpha+\beta 1 C S I+\beta 2 B C+\beta 3 A C+\beta 4 R O A+\beta 5 D E R+$ $\beta 6 \mathrm{CR}+$

$\beta 7 \mathrm{LnASSET}+\mathrm{e}$

Model 3: PBV $=\alpha+\beta 1$ CSI $+\beta 2$ ROA $+\beta 3$ DER $+\beta 4 C R+\beta 5$ LnASSET $+e$ Model4: $\quad \mathrm{PBV}=\alpha+\beta 1 \mathrm{CSI}+\beta 2 \mathrm{BC}+\beta 3 \mathrm{AC}+\beta 4 \mathrm{ROA}+\beta 5 \mathrm{DER}+$ $\beta 6 \mathrm{CR}+$

$\beta 7 \operatorname{LnASSET}+\mathrm{e}$

Model 5: $\quad$ ROA $=\alpha+\beta 1 \mathrm{CSI}+\beta 2 \mathrm{ROA}+\beta \mathrm{DER}+\beta 4 \mathrm{CR}+$ $\beta 5 \operatorname{LnASSET}+\mathrm{e}$

Model 6: $\mathrm{ROA}=\alpha+\beta 1 \mathrm{CSI}+\beta 2 \mathrm{BC}+\beta 3 \mathrm{AC}+\beta 4 \mathrm{ROA}+\beta 5 \mathrm{DER}+$ $\beta 6 \mathrm{CR}$

$\beta 7 \operatorname{LnASSET}+\mathrm{e}$

Where:

Tobin's q = Ratio of Tobin's q.

CSI = Corporate Sustainability Index

ROA = Return on Asset

DER $=$ Debt to Equity Ratio

$\mathrm{CR}=$ Current Ratio

LnASSET $=$ Logarithm of Total Asset

$\mathrm{BC}=$ Board of Commissioners

$\mathrm{AC}=$ Audit Committee

4. Data Analysis and Discussion

\subsection{Descriptive Statistics Analysis}

Data obtained from the National Center for Sustainability Reporting (NCSR), and the company's official web pages, the number of listed companies as participants ISRA are 49 and 35 are public companies listed in Indonesian stock exchanges as well. Of these, only 15 companies with 75 observations met the criteria for the research sample that had been set. Table 1 shown descriptive statistics of variables utilized in this study. 
Table 1. Descriptive Statistics

\begin{tabular}{|l|c|c|c|c|c|}
\hline & N & Minimum & Maximum & Mean & Std. Deviation \\
\hline Tobins' q & 75 & .63 & 9.48 & 1.5561 & 1.14207 \\
CSI & 75 & 22.62 & 100.00 & 71.9769 & 21.40263 \\
CR & 75 & .74 & 387.44 & $1.1978 \mathrm{E} 2$ & 96.48283 \\
DER & 75 & .37 & 18.91 & 2.5376 & 3.24101 \\
ROA & 75 & -15.40 & 20.49 & 5.0595 & 6.66357 \\
PBV & 75 & .02 & 4.17 & 2.0079 & 2.39549 \\
BC & 75 & 4.00 & 11.00 & 6.4000 & 1.59391 \\
AC & 75 & 3.00 & 6.00 & 3.6667 & .87508 \\
LnASSET & 75 & 15.48 & 20.38 & 17.6479 & 1.19188 \\
Valid N & 75 & & & & \\
(listwise) & & & & & \\
\hline
\end{tabular}

The mean or average Tobin's $q$ variable is 1.5561 and the minimum value of 0.63 occurred at PT. Petrosea Tbk in 2015. The maximum value is 9.48 , which occurred at PT. Bukit Asam Tbk in 2013. The mean value for the other dependent variable is PBV of 2.00, with a minimum value of 0.02 at PT. Bakri Sumatera Plantations Tbk in 2014, and a maximum value of 4.17 at PT. Wijaya Karya Tbk in 2013. The mean value of the other dependent variable, ROA, is 5.05, with a minimum value of -15.40 at PT. Bakrie Sumetera Plantations Tbk in 2013 and a maximum value of 20.49 at PT. Perusahaan Gas Negara Tbk in 2013.

For the CSI dependent variable, the mean is 71.9769 , and the minimum value is actually 22.62 at PT. United Traktor Thk in 2013 and 2014. The maximum value of 100 occurred at PT. Aneka Tambang Tbk in 2014 and PT. Semen Indonesia in 2014 and 2015, PT. Telekomunikasi Indonesia Tbk in 2013, PT. Wijaya Karya Tbk in 2015, PT. Indika Energy Tbk in 2015, and PT. Bukit Asam Tbk in 2015. The mean value for the $\mathrm{BC}$ variable is 6.40 , with a minimum value of 4.00 at PT. Indika Energy Thk in 2013-2016 and a maximum value of 11.00 at PT. Astra International Tbk in 2013-2016. The mean value for the AC variable is 3.66 , the minimum value is 3.00 and the maximum value is 6.00 .

\subsection{Hypothesis Testing Result}

The hypothesis testing results concerning the effect of a sustainable company index (CSI) on company value, as measured by using three alternatives of firm value as dependent variables with employed of three alternatives of estimation techniques as presented in Table 2. Based on the results of hypothesis testing in Table 2, of the six models used to explain the value of the company, it is concluded that CSI, and two variables of corporate governance, namely; the board of commissioners (DK) and the audit committee (KA), have a positive impact on the public companies' value which are registered in IDX.

From the results of hypothesis testing, it can be concluded that the CSI and corporate governance (BC and AC) variables reject the alternative hypotheses. However, of the six models used in the study, some of the models show that the CSI, BC, and AC variable coefficients have a positive effect on firm value. The results of this study support previous studies by Eccles et al. (2014); Lourenco et al (2012), and Wagner (2010), which state that the relationship between the disclosure of corporate sustainability on the American Stock Exchange has a positive influence on firm value. Likewise, the influence of corporate governance variables has a positive impact on the performance of companies that actively implement good corporate governance (Jo and Harjoto, 2011).

The limitations of the company sustainability index(CSI) variable and corporate governance variables in explaining the value of companies listed on the Indonesia Stock Exchange are probably due to the limited availability of public companies in disclosing involvement in environmental activities and corporate social responsibility. According to capital security law No. 25 of 2007, companies engaged in natural resource activities are required to carry out social responsibility and the principles of good corporate governance. However, these provisions have not been fully implemented properly, so the contribution of the companies in maintaining the sustainability of natural resources and social activities is still limited. 


\begin{tabular}{|c|c|c|c|c|c|c|}
\hline Variable & $\begin{array}{l}\text { Model } 1 \\
\text { Tobins" q }\end{array}$ & $\begin{array}{l}\text { Model } 2 \\
\text { Tobins'q }\end{array}$ & $\begin{array}{c}\text { Model } 3 \\
\text { PBV }\end{array}$ & $\begin{array}{c}\text { Model } 4 \\
\text { PBV }\end{array}$ & $\begin{array}{l}\text { Model } 5 \\
\text { ROA }\end{array}$ & $\begin{array}{c}\text { Model } 6 \\
\text { ROA }\end{array}$ \\
\hline $\mathrm{C}$ & $30.6148^{* 8 *}$ & 3.1948 & 6.1729 & $9.7288 *$ & $76.4173^{* *}$ & 17.3656 \\
\hline CSI & 0.0004 & 0.0050 & -0.0090 & -0.0129 & 0.0054 & 0.0112 \\
\hline $\mathrm{BC}$ & - & 0.0625 & - & 0.1983 & & 1.4258 \\
\hline $\mathrm{AC}$ & - & -0.0438 & - & 0.3929 & & 1.6658 \\
\hline ROA & 0.0866 & $0.1131^{* * *}$ & $0.0826 *$ & 0.0627 & & - \\
\hline GPM & - & - & - & - & $0.3437^{* * *}$ & $0.3919 * * *$ \\
\hline DER & -0.0242 & 0.0356 & -0.1427 & -0.1100 & -0.1914 & -0.2736 \\
\hline $\mathrm{CR}$ & $0.0080^{* 8}$ & 0.0014 & $-0.0064^{*}$ & $-0.0064^{*}$ & -0.0068 & -0.0017 \\
\hline InASSET & $-1.7244^{* * *}$ & -0.1746 & -0.1589 & -0.4968 & $-4.4668^{* *}$ & $-2.0562^{*}$ \\
\hline R-squared & 0.5876 & 0.4355 & 0.1001 & 0.1225 & 0.8743 & 0.3966 \\
\hline $\begin{array}{c}\text { Adjusted R- } \\
\text { squared }\end{array}$ & 0.4451 & 0.3765 & 0.0399 & 0.0308 & 0.8308 & 0.3336 \\
\hline F-statistic & $4.1246^{* * *}$ & $7.3852^{* * *}$ & 1.5366 & 1.3366 & $20.1352^{* * *}$ & $6.2921^{* * *}$ \\
\hline DW Stat & 1.5665 & 1.2983 & 2.5551 & 2.6436 & 1.8898 & 1.4146 \\
\hline $\begin{array}{l}\text { Estimation } \\
\text { technique }\end{array}$ & Fixed Effect & $\begin{array}{l}\text { Common } \\
\text { Effect }\end{array}$ & $\begin{array}{c}\text { Common } \\
\text { Effect }\end{array}$ & $\begin{array}{c}\text { Common } \\
\text { Effect }\end{array}$ & Fixed Effect & $\begin{array}{c}\text { Random } \\
\text { Effect }\end{array}$ \\
\hline
\end{tabular}

\section{Conclusion}

Companies involved in the disclosure of sustainable company reports and corporate governance are still limited, so the contribution of the variables has not been able to explain company performance as measured by Tobin's $q$, the ROA, and PBV variables. The companies are advised to be active and involved in activities to maintain the natural environment and play an active role in social responsibility and consistently apply good corporate governance.

The capital market authority should promote laws and regulations relating to the environmental and social aspects, and corporate governance towards business people so that it can be applied in every business activity and provide sanctions following prevailing invitations and regulations. Then, to investors, it is suggested that, in decision-making, the selection of investment portfolios should prioritize stocks and bonds as well as the investment instruments of companies that care about the environmental and social aspects and good corporate governance practice.

\section{REFERENCES}

Ammann, M., Oesch, D., and Schmid, M. M. (2011). Corporate governance and firm value: International evidence. Journal of Empirical Finance, Vol. 18, Issue. 1, pp. 36-55.

Artiach, T., Lee, D., Nelson, D., \& Walker, J. (2010). The determinants of corporate sustainability performance. Accounting \& Finance, 50(1), 31-51.

Bachoo, K., Tan, R., \& Wilson, M. (2013). Firm Value and the Quality of Sustainability Reporting in Australia. Australian Accounting Review No. 64 Vol. 23 Issue 1, pp. 67-87.

Burnett, R. D., Skousen, C. J., \& Wright, C.J. (2011). Eco-Effective Management: An Empirical Link between Firm Value and Corporate Sustainability. Accounting and the Public Interest, Vol. 11, pp. 1-15

Cheung, A. W. K. (2011). Do Stock Investors Value Corporate Sustainability? Evidence from an Event Study, Journal of Business Ethics, Vol. 99, Issue 2, pp. 145-165

Dowling, J., \& Pfefer, J. (1975). Organizational Legitimacy: Social Values and Organitational Behavior. Pacific Sociological Review.

Eccles, R. G., Serafeim, G. (2014). The Impacts of Corporate Sustainability on Organizational Processes and Performance. Management Science, Vol. 60, Issue 11, pp. 2835-2857. 
Eulerich, M., Velte, P., and Carolin, V. U (2014). Problems and The impact of management board diversity on corporate performance - an empirical analysis for the German two-tier system. Perspectives in Management, Volume 12, Issue 1, 2014. 1

Forum Corporate Governance Indonesia (FCGI), 2002. Peranan Dewan Komisaris dan Komite

Audit dalam pelaksanaan tatakelola perusahaan (corporate governance). Jakarta.

Global Reporting Initiatives (GRI). (2011). \&stainability Reporting Guidelines, Amsterdam.

Goyal, P., Rahman, Z., Kazmi, A.A. (2013). Corporate sustainability performance and firm performance research: Literature review and future research. Management Decision, Vol. 51, issue 2, pp. 361-379.

Guidry, R. P., and Patten, D. M. (2010). Market reaction to the first-time issuance of corporate sustainability reports: Evidence that quality matters. Sustainability Accounting, Management and Policy Journal, Vol. 1, Issue 1, pp. 33-50.

Guest, P.M. (2009). The impact of board size on firm performance: evidence from the UK, The European Journal of Finance, Volume 15, Issue 4, pp. 385-404

Harmon, J., Bucy, F., Nickbarg, Rao, G., and Wirtenberg. (2008). Developing a sustainability strategy, Book Chapter of The Sustainable Enterprise Fieldbook., edited by; Wirtenberg, J., Russell, W.G., and Lipsky, D. Greenleaf Publishing, UK.

Hörisch, J., Freeman R, E, and Schaltegger, S (2014). Applying Stakeholder Theory in Sustainability Management: Links, Similarities, Dissimilarities, and a Conceptual Framework. Organization \& Environment, May 2014, pp. 1-19

Jensen, M. C., and Meckling, W. H. (1976). Theory of the Firm: Managerial Behavior, Agency Cost, and Ownership Structure. Journal of Financial Economics, 3, 82-137.

Jo and Harjoto. (2011). Corporate Governance and Firm Value: The Impacts of Corporate Social Responsibility, Journal of Business Ethics, Vol. 103, Issue 3, pp. 351-383.

Kantabutra, S. (2019). Achieving Corporate Sustainability: Toward a Practical Theory. Sustainability, 11, 4155, pp. 1-39.

Kaspereit, T., and Lopatta, K. (2013). The Value Relevance of SAM's Corporate Sustainability Ranking and GRI Sustainability Reporting in the European Stock Markets. ZenTra Working paper in Transmatinnal Studies No. 19/2013. Downloaded from: Mtpsi/Tapers. Ssm.com, March 2018.

Lo, S-F., \& Sheu, H-J. (2007). Is Corporate Sustainability a ValueIncreasing Strategy for Business?. Corporate Governance, Vol. 15, No. 2, pp. 345-358.

Lourenco, I. C., Branco, M. C., Curto, J. D., and Eugenio, T. (2012). How Does the Market Value Corporate Sustainability Performance? Journal of Business Ethics, Vol. 108, Issue 4-, pp. 417-428.

Muller, V-O. (2014), The Impact of Board Composition on the Financial Performance of FTSE100 Constituents. Procedia-Social and Behavioral Sciences. Vol. 109, pp. 969-975.

Nguyen, H., \& Faff, R. (2007). Impact of board size and board diversity on firm value: Australian evidence. Corporate Ownership \& Control, 4(2), 24-32.

Saleh, M., Zulkifli, N., and Muhamad, R. (2011). Looking for evidence of the relationship between corporate social responsibility and corporate financial performance in an emerging market. Asia-Pacific Journal of Business Administration. Vol. 3, No. 2, pp. 165-190.

Salzmann, 0., and Steger, U. (2005). The Business Case for Corporate Sustainability: Literature Review and Research Options, European Management Journal, Vol. 23(1), pp. 27-35.

Sihotang, P., and Effendi, S (2009). Sustainability Reporting for CSR Disclosures: A case study in oil and gas industry, Jurnal Kajian Ekonomi dan Keuangan. Vol. 13, No.1.

Singh, P. J., Sethuraman, K., and Lam, J. Y. (2017). Impact of Corporate Social Responsibility Dimensions on Firm Value: Some Evidence from Hong Kong and China. Sustainability, 9(9).

Yu, M \& Zhao, R (2015). Sustainability and firm valuation: an international investigation. International Journal of Accounting and Information Management, Vol. 23 Iss 3 pp. 289 - 307 
Wagner, M. (2005). How to reconcile environmental and economic performance to improve corporate sustainability: corporate environmental strategies in the European paper industry. Journal of Environmental Management, Vol. 76, issue 2, pp. 105-118.

Wagner, M. (2010). Analysis the role of corporate sustainability performance for economic performance: A firm-level analysis of moderation effects, Ecological Economics, Vol. 69, Issue 7, pp. 1553-1560. 